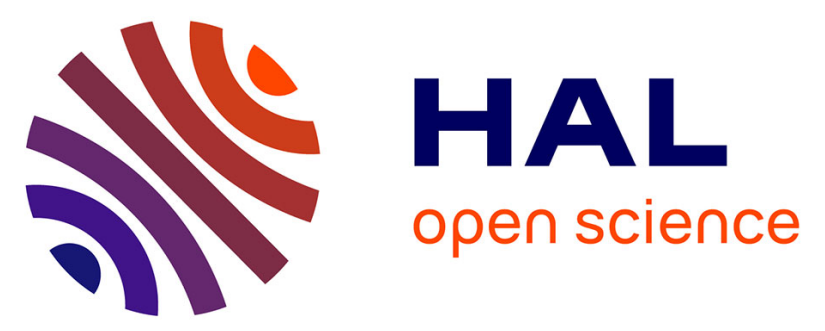

\title{
Proteolysis of ultra high temperature-treated casein micelles by AprX enzyme from Pseudomonas fluorescens $F$ induces their destabilisation
}

François Baglinière, Aurélie Matéos, Gaëlle Tanguy-Sai, Julien Jardin, Valérie

Briard-Bion, Florence Rousseau, Benoit Robert, Eric Beaucher, Jean-Luc

Gaillard, Caroline Amiel, et al.

\section{To cite this version:}

François Baglinière, Aurélie Matéos, Gaëlle Tanguy-Sai, Julien Jardin, Valérie Briard-Bion, et al.. Proteolysis of ultra high temperature-treated casein micelles by AprX enzyme from Pseudomonas fluorescens F induces their destabilisation. International Dairy Journal, 2013, 31, pp.55-61. 10.1016/j.idairyj.2013.02.011 . hal-01209417

\section{HAL Id: hal-01209417 \\ https://hal.science/hal-01209417}

Submitted on 29 May 2020

HAL is a multi-disciplinary open access archive for the deposit and dissemination of scientific research documents, whether they are published or not. The documents may come from teaching and research institutions in France or abroad, or from public or private research centers.
L'archive ouverte pluridisciplinaire HAL, est destinée au dépôt et à la diffusion de documents scientifiques de niveau recherche, publiés ou non, émanant des établissements d'enseignement et de recherche français ou étrangers, des laboratoires publics ou privés. 


\title{
Proteolysis of ultra high temperature-treated casein micelles by AprX enzyme from Pseudomonas fluorescens F induces their destabilisation
}

\author{
François Baglinière ${ }^{\mathrm{a}, \mathrm{b}, \mathrm{c}, \mathrm{d}}$, Aurélie Matéos ${ }^{\mathrm{c}, \mathrm{d}}$, Gaëlle Tanguy ${ }^{\mathrm{a}, \mathrm{b}}$, Julien Jardin ${ }^{\mathrm{a}, \mathrm{b}}$, \\ Valérie Briard-Bion $^{\mathrm{a}, \mathrm{b}}$, Florence Rousseau ${ }^{\mathrm{a}, \mathrm{b}}$, Benoît Robert ${ }^{\mathrm{a}, \mathrm{b}}$, Eric Beaucher ${ }^{\mathrm{a}, \mathrm{b}}$, \\ Jean Luc Gaillard ${ }^{\mathrm{d}}$, Caroline Amiel ${ }^{\mathrm{d}}$, Gérard Humbert ${ }^{\mathrm{c}}$, Annie Dary ${ }^{\mathrm{c}}$, \\ Frédéric Gaucheron ${ }^{\mathrm{a}, \mathrm{b}, *}$ \\ a INRA, UMR1253 Science et Technologie du Lait et de l'Euf, F-35042 Rennes, France \\ ${ }^{\mathrm{b}}$ AGROCAMPUS OUEST, UMR1253 Science et Technologie du Lait et de l'Euf, F-35042 Rennes, France \\ ' URAFPA, Université de Lorraine, INRA, Equipe Protéolyse-Biofonctionnalité des Protéines et des Peptides, Boulevard des aiguillettes, BP239, 54506 \\ Vandœuvre-lès-Nancy, France \\ ${ }^{\mathrm{d}}$ Unité de Recherche Aliments Bioprocédés Toxicologie Environnements (UR ABTE) EA 4651, Université de Caen Basse-Normandie, Boulevard du Maréchal \\ Juin, F 14032 Caen, France
}

\section{A R T I C L E I N F O}

\section{Article history:}

Received 18 October 2012

Received in revised form

30 January 2013

Accepted 18 February 2013

\begin{abstract}
A B S T R A C T
Destabilisation of ultra high temperature (UHT) treated milk has been linked to residual proteolytic activity after UHT treatment. To understand the physico-chemical modifications of casein micelles by the protease AprX, produced by Pseudomonas fluorescens F, this enzyme was purified and added to raw milk before UHT treatment. Destabilisation of the UHT milk, over three months of storage, was investigated at macroscopic, colloidal and molecular scales. A visual destabilisation appeared progressively over time. At colloidal scale, aggregates were formed and a parallel decrease in zeta potential and hydration of casein micelles was observed. At molecular scale, peptides were released from casein micelles and identified by reversed-phase liquid chromatography coupled with tandem mass spectrometry. The $\alpha_{\mathrm{S} 1^{-}}, \alpha_{\mathrm{S} 2^{-}}, \beta-$ and $\kappa^{-}$ caseins were hydrolysed, with a preference for $\beta$-casein. The results were consistent with the proposition that proteolysis by Ps. fluorescens leading to the destabilisation of milk was due to the activity of AprX. (c) 2013 Elsevier Ltd. All rights reserved.
\end{abstract}

\section{Introduction}

Combined with an aseptic packaging, ultra high temperature (UHT) treatment offers safe drinking milk that can be stored at ambient temperature for several months. Nevertheless, destabilisation, with formation of gel or sediment, sometimes appears in commercial UHT milk samples during storage.

In the last decade, a number of different studies have tried to find the causes of this destabilisation. The main probable cause is the presence of psychrotrophic species in raw milk (Dogan \& Boor, 2003). Psychrotrophic bacteria are a heterogeneous group of Gramnegative bacteria found in soil, water, and food like fish, meat and milk (McPhee \& Griffiths, 2011; Martins, Pinto, Rocha, de Arujo, \& Vanetti 2006; Nörnberg, Friedrich, Weiss, Tondo, \& Brandelli, 2010; Teh, Flint, Palmer, Lindsa, Andrewes, \& Bremer, 2011; Wang \& Jayaro, 2001). These bacteria grow at low temperature and can

\footnotetext{
* Corresponding author. Tel.: +33223485750.

E-mail address: frederic.gaucheron@rennes.inra.fr (F. Gaucheron).
}

produce extracellular proteases. With its enzymatic profile, Pseudomonas fluorescens is frequently implicated in the spoilage of food, particularly dairy products; this spoilage leads to bitter flavour and gelation of milk during its storage.

Ps. fluorescens secretes AprX, an extracellular and heat-resistant protease (Sørhaug \& Stepaniak, 1997). Using azocasein as substrate, Dufour et al. (2008) estimated that the activity of the protease was optimal at $\mathrm{pH} 8.5$ and $45^{\circ} \mathrm{C}$. This protease belongs to the serralysin family and has been characterised. The presence of zinc, calcium and the absence of $\mathrm{S}-\mathrm{S}$ bridges in the protein could be the cause of its thermostability (Adams, Barach, \& Speck, 1975, 1976; Richardson \& Te Whaiti, 1978). The enzyme activity of AprX from Ps. fluorescens CY091 was almost completely inhibited in the presence of $1 \mathrm{~mm}$ 1,10-phenanthroline (a divalent-ion chelator), but only $30 \%$ of the activity was inhibited in the presence of $1 \mathrm{~mm}$ EGTA (a Ca ${ }^{2+}$ chelator). This result indicated that divalent cations, $\mathrm{Ca}^{2+}$ and $\mathrm{Zn}^{2+}$, are required for the activity and stability of the AprX enzyme (Liao \& McCallus, 1998). Its gene location within operonic structures was identified in a few strains. The organisation of this operon differs from one strain to another (Ahn, Pan, \& Rhee, 1999; 
Liao \& McCallus, 1998; Woods, Burger, Beven, \& Beacham, 2001). The operon contains genes encoding protease inhibitor, auto transporter proteins, lipase and protease secretion. The aprX gene is present in several genus and species such as Pseudomonas fragi, Pseudomonas chlororaphis, Pseudomonas tolaasi, Pseudomonas aeruginosa, Serratia marcescens and Flavobacterium cytophaga isolated from soil (Marchand et al., 2009; Martins, de Araujo, Mantovani, Moraes, \& Vanetti, 2005).

To investigate the impact of this extracellular protease on the quality of UHT milk, the proteolysis of casein micelles by a purified protease AprX and consequences thereof were studied at macroscopic, colloidal and molecular scale. The enzyme was selected from the strain Ps. fluorescens F isolated from raw milk (Dufour et al., 2008), which was selected for its high proteolytic potential (Baglinière et al., 2012).

\section{Materials and methods}

\subsection{Culture of Ps. fluorescens $F$ and purification of extracellular protease}

Ps. fluorescens $\mathrm{F}$ was grown in complex medium (meat extract powder $3 \mathrm{~g} \mathrm{~L}^{-1}$, peptone from casein $5 \mathrm{~g} \mathrm{~L}^{-1}$ and $0.6 \mathrm{mM} \mathrm{CaCl}_{2}$ ) for $72 \mathrm{~h}$ at $25{ }^{\circ} \mathrm{C}$ with stirring at $160 \mathrm{rpm}$. Cells were removed by centrifugation at $3900 \times g$ at $20^{\circ} \mathrm{C}$ for $15 \mathrm{~min}$. The cell-free supernatant was dialysed against ultra-pure water containing $0.02 \%(\mathrm{w} / \mathrm{v})$ $\mathrm{NaN}_{3}$ at $7{ }^{\circ} \mathrm{C}$ for $48 \mathrm{~h}$ and lyophilised. The lyophilised sample was dissolved at $10 \mathrm{mg} \mathrm{mL}^{-1}$ in a solution containing $50 \mathrm{~mm}$ Tris- $\mathrm{HCl}$ buffer $\mathrm{pH} 7.5,150 \mathrm{~mm} \mathrm{NaCl}$ and $0.02 \%$ (w/v) $\mathrm{NaN}_{3}$. Ten $\mathrm{mL}$ of sample was then applied to a size-exclusion chromatographic column HiPrep Sephacryl 26/60 S-200 (column volume 320 mL, mean particle size $47 \mu \mathrm{m}$, exclusion limit $2.5 \times 10^{5} \mathrm{Da}$; GE Healthcare, Little Chalfont, Buckinghamshire, United Kingdom) equilibrated with the same buffer. Elution was carried out with linear flow rate of $2.5 \mathrm{~mL} \mathrm{~min}^{-1}$. Fractions with proteolytic activity (using azocasein as substrate) were collected, pooled, dialysed against ultra-pure water containing $0.02 \%(\mathrm{w} / \mathrm{v}) \mathrm{NaN}_{3}$ at $7{ }^{\circ} \mathrm{C}$ for $24 \mathrm{~h}$ and lyophilised. Sodium dodecyl sulphate polyacrylamide gel electrophoresis (SDS-PAGE) analysis was performed on these fractions to evaluate purity. The identification of the protease was performed by tandem mass spectrometry by the same method described by Dherbecourt et al. (2010).

\subsection{Milk treatments}

This protocol was described in detail by Gaucher et al. (2011). Briefly, raw milk was skimmed and microfiltered $(0.8 \mu \mathrm{m}$ pore size), After these steps, milk contained less than $10^{4}$ somatic cells $\mathrm{mL}^{-1}$ and 10 colony-forming unit (cfu) $\mathrm{mL}^{-1}$ (total bacteria). One part of the microfiltered milk was used as control milk and the second was mixed with the purified protease AprX to obtain a final concentration of AprX about $0.2 \mathrm{mg} \mathrm{L}^{-1}$. Heat treatments of both samples of milk (with or without AprX) were performed with an indirect UHT processing system (Microthermics UHT/HTST Lab 25 EDH, Microthermics, Inc., Raleigh, NC 27615, USA). Milk was preheated to $90^{\circ} \mathrm{C}$ in a first tubular heat exchanger, heated to $140{ }^{\circ} \mathrm{C}$ in a second heat exchanger and maintained at $140^{\circ} \mathrm{C}$ for $4 \mathrm{~s}$. After immediate cooling to $17^{\circ} \mathrm{C}$, glass bottles (volume $250 \mathrm{~mL}$ ) were aseptically filled.

\subsection{Physico-chemical characterisation of UHT milk during storage}

The different UHT milk samples were analysed after 1, 8, 30, 60 and 90 days of storage at about $20^{\circ} \mathrm{C}$. By enumeration on a plate count agar medium ( 3 days of incubation at $30^{\circ} \mathrm{C}$ ), the absence of bacterial contamination was checked for each milk sample before analysis. The $\mathrm{pH}$ of all UHT milk samples was evaluated during the period of storage and fluctuated between 6.65 and 6.75 .

\subsubsection{Non casein and non protein nitrogen contents}

The soluble fraction of non casein nitrogen $(\mathrm{NCN})$ and non protein nitrogen (NPN) of the UHT milk were obtained after precipitation and filtration at $\mathrm{pH} 4.6$ for the NCN fraction and after precipitation with $12 \%$ trichloroacetic acid (TCA) and filtration for the NPN fraction. The NCN and NPN contents were determined using the Kjeldhal method according to IDF standard 20B (IDF, 2001). The experimental error was $\pm 0.1 \mathrm{~g}$ of protein $\mathrm{kg}^{-1}$.

2.3.2. Analysis of non casein nitrogen fraction by reversed phase high-performance liquid chromatography coupled to electrospray ionisation-tandem mass spectrometry

All mass spectra were performed using a hybrid quadrupole time of flight (Q/TOF) mass spectrometer QStar XL (MDS Sciex, Toronto, Canada). The instrument was calibrated with a multi-point calibration using fragment ions that resulted from the collisioninduced decomposition of a peptide from $\beta$-casein, $\beta$-casein (193-209) (NeoMPS S.A., Strasbourg, France). After 1:50 dilution in $0.1 \%$ trifluoroacetic acid (TFA) (Pierce, Touzart et Matignon, Vitrysur-Seine, France), the peptide fraction $(10 \mu \mathrm{L})$ was trapped onto a micro-pre-column cartridge $C_{18}$ PepMap $100 \quad(300 \mu \mathrm{m}$ i.d. $\times 5 \mathrm{~mm}$, Dionex, Sunnyvale, CA, USA) before separation of peptides onto a $C_{18}$ column PepMap $100(75 \mu \mathrm{m}$ i.d. $\times 250 \mathrm{~mm}$, Dionex). The separation started with $5 \%$ solvent $\mathrm{B}$ for $5 \mathrm{~min}$ and a linear gradient from 5 to $50 \%$ of solvent B for 75 min was performed at a flow rate of $300 \mathrm{~nL} \mathrm{~min}{ }^{-1}$ on a Dionex U3000 RSLC system. Solvent A contained $2 \%$ acetonitrile, $0.08 \%$ formic acid and $0.01 \%$ TFA in LC grade water and solvent B contained 95\% acetonitrile, $0.08 \%$ formic acid and $0.01 \%$ TFA in LC grade water.

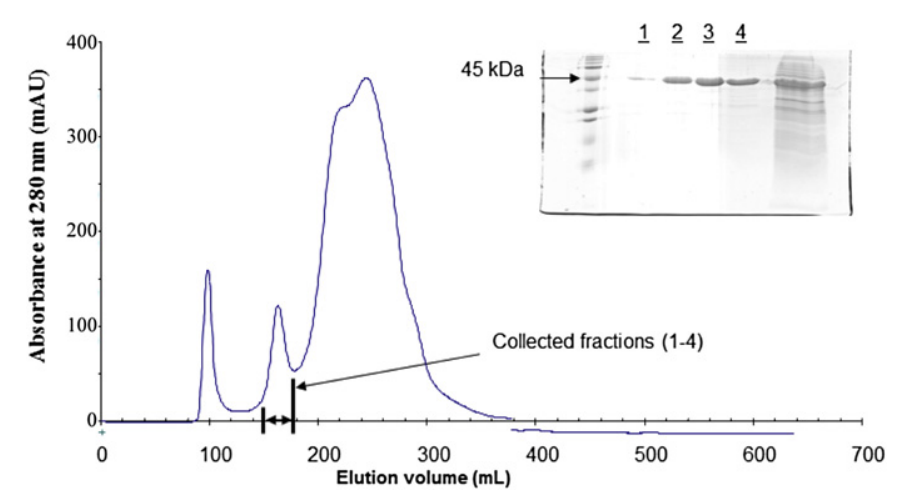

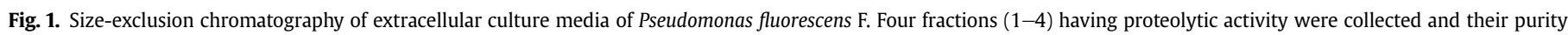
was checked by sodium dodecyl sulphate polyacrylamide gel electrophoresis (inset). 


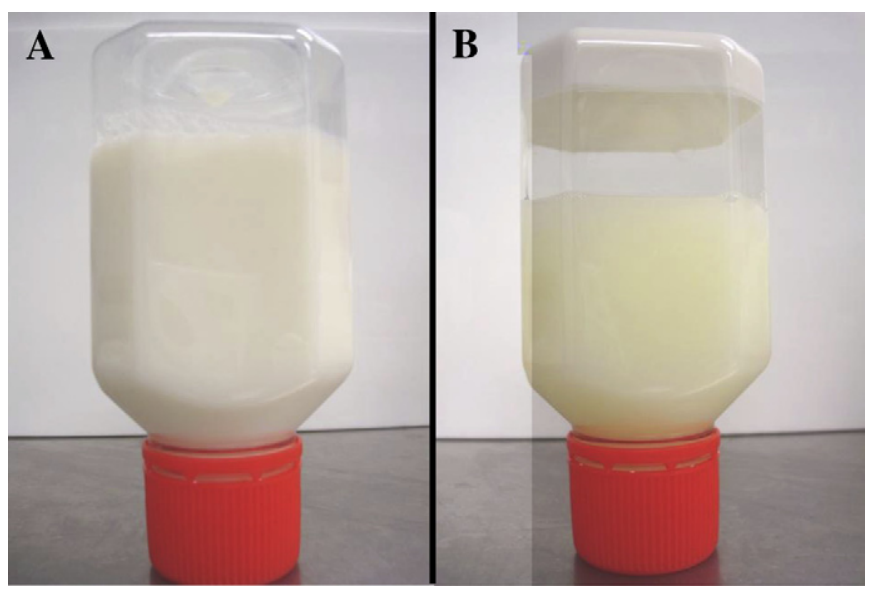

Fig. 2. Photographs of the bottles of control UHT milk (A) and UHT milk containing AprX (B) both after 90 days of storage.

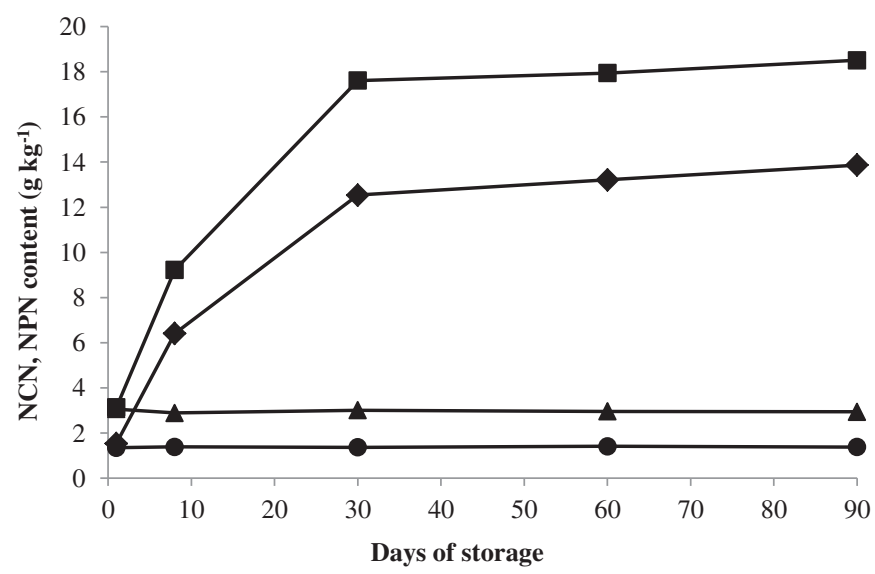

Fig. 3. Non-casein and non-protein nitrogen contents of control UHT milk ( $\boldsymbol{\Delta}$ and $\boldsymbol{\bullet}$ respectively) and UHT milk containing $0.2 \mathrm{mg} \mathrm{L}^{-1}$ of AprX ( $\mathbf{\square}$ and $\bullet$, respectively) during 90 days of storage at $20^{\circ} \mathrm{C}$.

The separated peptides were analysed by electrospray ionisation. This protocol and the method used to identify peptides were described in detail by Bouzerzour et al. (2012), with some modifications. For the identification of peptides, the Swissprot database Uniprot (http://www.uniprot.org) was used. Phosphorylation of serine and threonine residues was selected as a variable modification, as well as oxidation of methionine and deamidation of asparagine and glutamine residues. For the identification of the protease, the Uniprot/Trembl database was used with trypsin enzymatic cleavage. For each peptide identified, a minimum MASCOT score of at least 36, corresponding to a $p$-value of $<0.05$, was considered as a prerequisite for peptide validation with a high degree of confidence.

\subsubsection{Hydration of milk particles}

The protocol for hydration of particles was described in detail by Gaucher et al. (2011). Hydration of particles was obtained by the determination of the water content of the pellet obtained after ultracentrifugation of milk for $1 \mathrm{~h}$ at $100,000 \times \mathrm{g}$ at $20^{\circ} \mathrm{C}$ (Sorvall Discovery $90 \mathrm{SE}$, Sorvall, Courtaboeuf, France). Pellets were weighed and dried for $7 \mathrm{~h}$ at $103{ }^{\circ} \mathrm{C}$. The water contents of the ultracentrifuged pellet were expressed in $\mathrm{g}$ of water per $\mathrm{g}$ of dried pellet. This water content is the difference between the weights before and after drying. The experimental error was $\pm 0.1 \mathrm{~g}$ water $\mathrm{g}^{-1}$ dried pellet.

\subsubsection{Zeta potential of milk particles}

The protocol for determining the zeta potential of milk particles was described in detail by Gaucher et al. (2011). The instrument used was a Zetasizer Nano ZS (Malvern Instruments, Worcestershire, United Kingdom). Before analysis, milk samples were diluted 1/100 in their corresponding ultrafiltrate (molecular mass cut-off: $10 \mathrm{kDa}$ ) Measurements were performed at a scattering angle of $173^{\circ}$ and a wavelength of $633 \mathrm{~nm}$. A $50 \mathrm{~V}$ voltage and a dielectric constant of 80 were applied for this analysis. The Smoluchowskis (1917) equation based on electrophoretic mobility was used to determinate the negative charge of micelles. The experimental error was $\pm 1 \mathrm{mV}$.

\subsubsection{Size distribution of milk particles}

The distribution of the particle sizes in milk was determined by laser light scattering. Milks were directly injected into the dispersion cell (containing deionised water under agitation at $1500 \mathrm{rpm}$ ) of a Mastersizer 2000 granulometer (Malvern Instruments Ltd, Worcestershire, United Kingdom). The refractive indexes used in this study were 1.570 for casein micelles and 1.333 for water (Griffin \& Griffin, 1985). The experimental error on the average size was $\pm 5 \mathrm{~nm}$.

\section{Results}

\subsection{Purification of extracellular protease of Ps. fluorescens $F$}

A chromatographic profile of purification of extracellular protease of Ps. fluorescens $\mathrm{F}$ is shown in Fig. 1. Four fractions with the highest

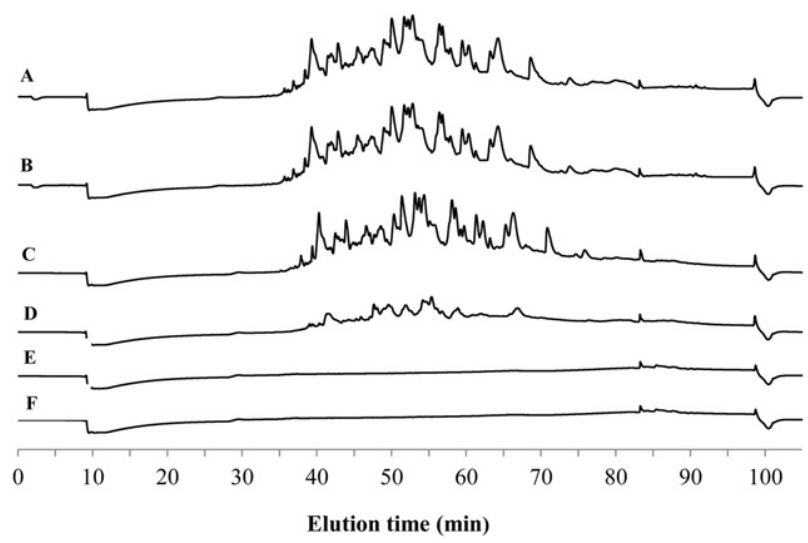

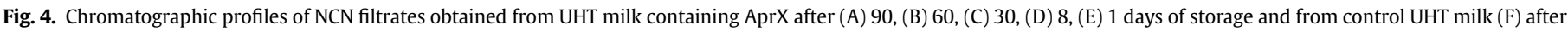
90 days of storage at $20^{\circ} \mathrm{C}$. 
proteolytic activity were collected (retention time between 140 and $175 \mathrm{~min}$ ), pooled and lyophilised. SDS-PAGE analysis was performed on these fractions and showed only one main homogeneous band after Coomassie blue staining, with an apparent molecular mass of about 45 kDa. In previous studies, Dufour et al. (2008) and Nicodème, Grill, Humbert, and Gaillard (2005) obtained a similar apparent molecular mass for the protease AprX. The identity of the electrophoresis band was confirmed by tandem mass spectrometry to be the protein Q7X4S5 in UniprotKB; this is the extracellular alkaline protease from gene aprX of Ps. fluorescens (data not shown).

\subsection{Visual observation of UHT milk samples after 3 months of storage}

After 90 days storage, no sign of destabilisation was observed for control UHT milk (bottle A in Fig. 2); the milk remained liquid and
A

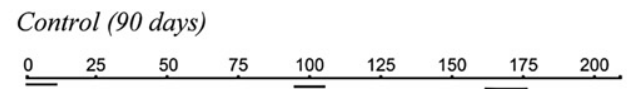

Aprx (1 day)

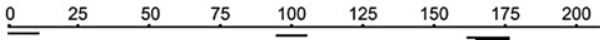

AprX (8 days)
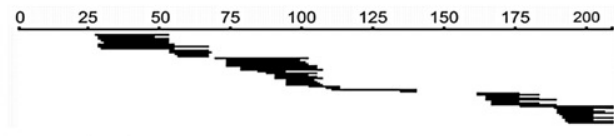

AprX (30 days)

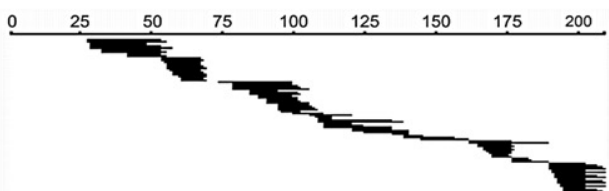

AprX (60 days)

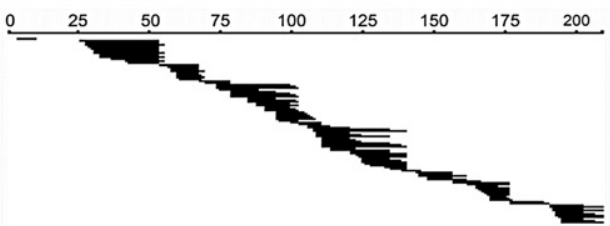

AprX (90) days

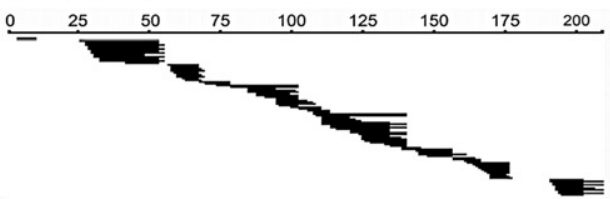

D Control ( 90 days)

\begin{tabular}{lcccccc}
0 & 25 & 50 & 75 & 100 & 125 & 150 \\
\hline $\begin{array}{llllll}\text { Aprx (1 day) } \\
0\end{array}$ & 25 & 50 & 75 & 100 & 125 & 150 \\
\hline & & & & & \\
AprX (8 days) \\
0 & 25 & 50 & 75 & 100 & 125 & 150 \\
\hline
\end{tabular}

AprX (30 days)

\begin{tabular}{lllllll}
0 & 25 & 50 & 75 & 100 & 125 & 150 \\
\hline
\end{tabular}

AprX (60 days)

\begin{tabular}{lllllll}
0 & 25 & 50 & 75 & 100 & 125 & 150 \\
\hline
\end{tabular}

AprX (90) days

\begin{tabular}{lllllll}
0 & 25 & 50 & 75 & 100 & 125 & 150 \\
\hline
\end{tabular}
B Control (90 days)

\begin{tabular}{llllllll}
0 & 25 & 50 & 75 & 100 & 125 & 150 & 175 \\
\hline
\end{tabular}

Aprx (1 day)

\begin{tabular}{llllllll}
0 & 25 & 50 & 75 & 100 & 125 & 150 & 175 \\
\hline
\end{tabular}

AprX (8 days)

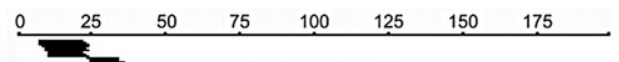

AprX (30 days)

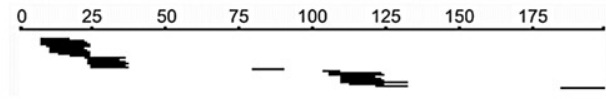

AprX (60 days)

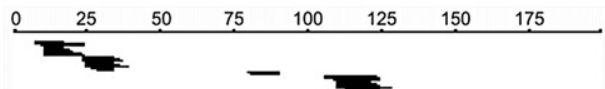

AprX (90) days

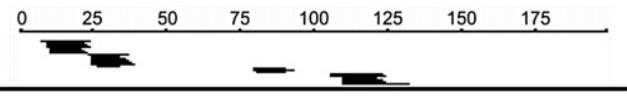

C

Control ( 90 days)

\begin{tabular}{lllllllll}
0 & 25 & 50 & 75 & 100 & 125 & 150 & 175 & 200 \\
\hline
\end{tabular}

Aprx (1 day)

\begin{tabular}{lllllllll}
0 & 25 & 50 & 75 & 100 & 125 & 150 & 175 & 200 \\
\hline
\end{tabular}

AprX (8 days)

\begin{tabular}{lllllllll}
0 & 25 & 50 & 75 & 100 & 125 & 150 & 175 & 200 \\
\hline
\end{tabular}

AprX (30 days)

\begin{tabular}{lllllllll}
0 & 25 & 50 & 75 & 100 & 125 & 150 & 175 & 200 \\
\hline
\end{tabular}

AprX (60 days)

\begin{tabular}{lllllllll}
0 & 25 & 50 & 75 & 100 & 125 & 150 & 175 & 200 \\
\hline
\end{tabular}

AprX (90) days

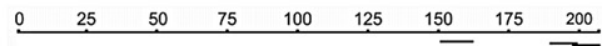

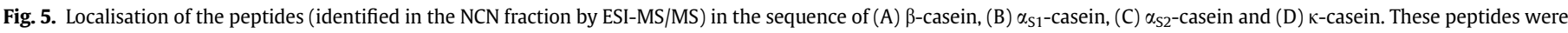
detected in the NCN fraction of UHT milk containing AprX and from control UHT milk during 90 days of storage at $20{ }^{\circ} \mathrm{C}$. 
Table 1

Number of peptides identified for each casein in the NCN filtrate of UHT milk control and UHT milk containing AprX after 1, 8, 30, 60 and 90 days of storage. Peptides were identified by RP-HPLC coupled to ESI-MS/MS.

\begin{tabular}{llllcrc}
\hline \multirow{2}{*}{ Casein } & $\begin{array}{l}\text { Control } \\
\text { 90 days }\end{array}$ & \multicolumn{6}{l}{ UHT milk containing AprX } \\
\cline { 3 - 7 } & & 1 day & 8 days & 30 days & 60 days & 90 days \\
\hline$\beta$-casein & 5 & 5 & 53 & 87 & 104 & 91 \\
$\alpha_{\mathrm{S} 1}$-casein & 0 & 0 & 16 & 27 & 27 & 23 \\
$\alpha_{\mathrm{S} 2}$-casein & 0 & 0 & 1 & 3 & 2 & 5 \\
$\kappa$-casein & 0 & 0 & 0 & 2 & 5 & 3 \\
Total & 5 & 5 & 70 & 119 & 138 & 122 \\
\hline
\end{tabular}

homogeneous. Conversely, UHT milk containing $0.2 \mathrm{mg} \mathrm{L}^{-1}$ of AprX was destabilised, with the presence of white sediment (bottle B in Fig. 2). Similar results were observed by Gaucher et al. (2011) with strain Ps. fluorescens CNRZ 798 and Baglinière et al. (2012) with strain Ps. fluorescens F.

\subsection{Changes in NCN and NPN contents during storage of UHT milk samples}

For control UHT milk, the NCN content was about $3.1 \mathrm{~g} \mathrm{~kg}^{-1}$ immediately after UHT treatment (Fig. 3). The cause of this low value compared with raw milk $\left(7-8 \mathrm{~g} \mathrm{~kg}^{-1}\right)$ was the association of casein molecules with denatured whey proteins, ( $\alpha$-lactalbumin, $\beta$ lactoglobulin and immunoglobulins) during UHT treatment (Gaucher et al., 2011). The NCN content of control UHT milk did not increase during 90 days of storage.

For UHT milk samples containing $0.2 \mathrm{mg} \mathrm{L}^{-1}$ of purified AprX, an increase of the NCN content was observed after the first week of storage to a value of $9.2 \mathrm{~g} \mathrm{~kg}^{-1}$. Then, an increase was observed during the storage, reaching about $18.5 \mathrm{~g} \mathrm{~kg}^{-1}$ after 90 days of storage (Fig. 3). Similar result was obtained with the strain Ps. fluorescens $\mathrm{F}$ (Baglinière et al., 2012).

The initial NPN content of the control UHT milk was $1.4 \mathrm{~g} \mathrm{~kg}^{-1}$ (Fig. 3), due to the presence of small molecules containing nitrogen (creatine, urea, peptides and free amino acids). The NPN value remained stable during the 90 days of storage. These results were in accordance with those reported by Gaucher et al. (2009, 2011). For UHT milk containing AprX, an increase of the NPN content up to $6.2 \mathrm{~g} \mathrm{~kg}^{-1}$ was observed after one week of storage. NPN content reached $13.9 \mathrm{~g} \mathrm{~kg}^{-1}$ after 90 days of storage (Fig. 3). A similar result was obtained with the strain Ps. fluorescens F and some other strains of Ps. fluorescens (Baglinière et al., 2012).

\subsection{Separation and identification of peptides present in the NCN fractions by RP-HPLC coupled to ESI-MS/MS}

After 90 days of storage, the intensity of chromatographic profile of the peptides present in the NCN fraction of the control UHT milk was low (Fig. 1). For UHT milk containing AprX, the chromatographic profile at one day after UHT treatment was similar to that of the NCN fraction just after the UHT treatment. Then, after 8 days of storage, an increase in the signal of the chromatographic profiles of the NCN was observed. This signal increased during the storage (30,60 and 90 days; Fig. 4). At the end of storage, the total chromatographic area for the destabilised UHT milk was fifteen-fold higher than those obtained for the control UHT milk (result not shown).

The identification of different peptides present in the NCN fractions was performed by ESI-MS/MS after their separation by RP-HPLC. At different times of storage, the quantity of peptides identified in the NCN fraction of the control UHT milk was relatively limited. Only a few peptides coming from $\beta$-casein were detected (Fig. 5, Table 1). For the NCN fraction of UHT milk
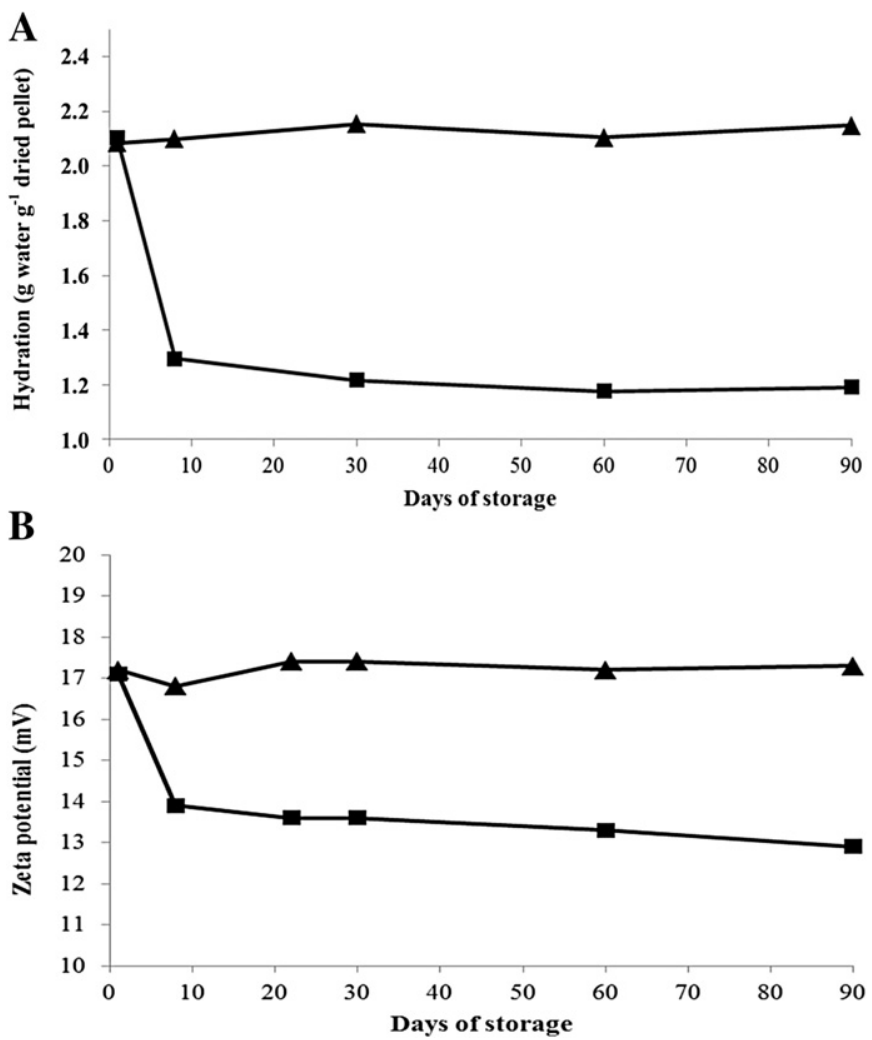

Fig. 6. Hydration (A) and zeta potential (B) of ultracentrifugal-pellets from control UHT milk ( $\boldsymbol{\Delta}$ ) and UHT milks containing AprX ( $\boldsymbol{\square})$ during 90 days of storage at $20{ }^{\circ} \mathrm{C}$. 
containing AprX, several peptides were detected during storage. Peptides originating from $\beta$ - and $\alpha_{S 1}$-caseins were detected after 8 days of storage. The number of different peptides coming from these caseins was 53 after 8 days of storage and increased until the end of storage (Fig. 5 and Table 1 ). For $\beta$-casein, no specific cleavage was observed. Peptides belonging to the sequence $\beta$ casein 13-25 were not identified (Fig. 5A). For $\alpha_{S 1}$-casein, fewer peptides were detected than for $\beta$-casein, and peptides belonging to the sequences 5-35 and 105-125 were often detected (Fig. 5B). For $\alpha_{\mathrm{S}^{-}}$and $\kappa$-caseins (Fig. $5 \mathrm{C}$ and $\mathrm{D}$ respectively), only few peptides were detected after 30 days of storage. Overall the number of different peptides detected by mass spectrometry was of the order $\beta->\alpha_{\mathrm{S}^{-}}>\kappa^{-}>\alpha_{\mathrm{S} 2^{-}}$-caseins (Table 1).

\subsection{Hydration of particles during storage of UHT milk samples}

For control UHT milk, the values of hydration of particles during storage remained above $2.1 \pm 0.1 \mathrm{~g}$ of water per $\mathrm{g}$ of dried pellet (Fig. 6A). The initial value and its change were in accordance with values reported by Gaucher et al. (2011). For UHT milk samples containing AprX, the hydration decreased to reach about $1.3 \pm 0.1 \mathrm{~g}$ of water per $g$ of dried pellet after 8 days of storage. Between 30 and 90 days of storage, the values for hydration remained constant $(1.2 \pm 0.1 \mathrm{~g})$. A similar result was obtained with the strain Ps. fluorescens $\mathrm{F}$ (Baglinière et al., 2012). These low values were also described for destabilised UHT milk samples (Gaucher et al., 2009, 2011).

\subsection{Zeta potential of particles during storage of UHT milk samples}

For control UHT milk, the zeta potentials of particles remained constant during the 90 days of storage with an average value of $-17.3 \pm 1 \mathrm{mV}$ (Fig. $6 \mathrm{~B}$ ). This value was in accordance with those described in the literature (Gaucher et al., 2011). For UHT milk samples containing AprX, a decrease of the absolute value of zeta potential was observed after 8 days of storage, when the value reached $-13.9 \pm 1 \mathrm{mV}$. Between 8 and 90 days of storage, the absolute value of zeta potential slightly decreased to reach $-12.9 \pm 1 \mathrm{mV}$. A similar result was obtained for milk containing the F strain of Ps. fluorescens (Baglinière et al., 2012) and these low values of zeta potential were also obtained for unstable UHT milk samples (Gaucher et al., 2011).

\subsection{Size distribution of particles during storage of UHT milk samples}

The particle size distribution of the control UHT milk was determined to be monodisperse, with sizes ranging between $0.05 \mu \mathrm{m}$ and $0.32 \mu \mathrm{m}$. The average particle size of $0.2 \mu \mathrm{m}$ corresponded to casein micelles (Fig. 7). The size distributions were similar whatever the time of storage (data not shown).

For UHT milk containing $0.2 \mathrm{mg} \mathrm{L}^{-1}$ of AprX, a new population appeared after 8 days of storage, with a particle size between 0.7 and $9 \mu \mathrm{m}$. The average particle size of $0.2 \mu \mathrm{m}$ corresponding to stable casein micelles was still present, but at a lower level. After 30 days of storage, the average particle size of $0.2 \mu \mathrm{m}$, corresponding to casein micelles, was not present, and a new population appeared with a diameter between 2 and $700 \mu \mathrm{m}$. The nature of this population could be aggregates, but this was not determined in this study. The particle size distribution of the UHT milk containing AprX was similar after 30, 60 and 90 days. The presence of these types of particles was also observed in UHT milk samples contaminated by the strains Ps. fluorescens CNRZ 798 (Gaucher et al., 2011) and $\mathrm{F}$ (Baglinière et al., 2012).

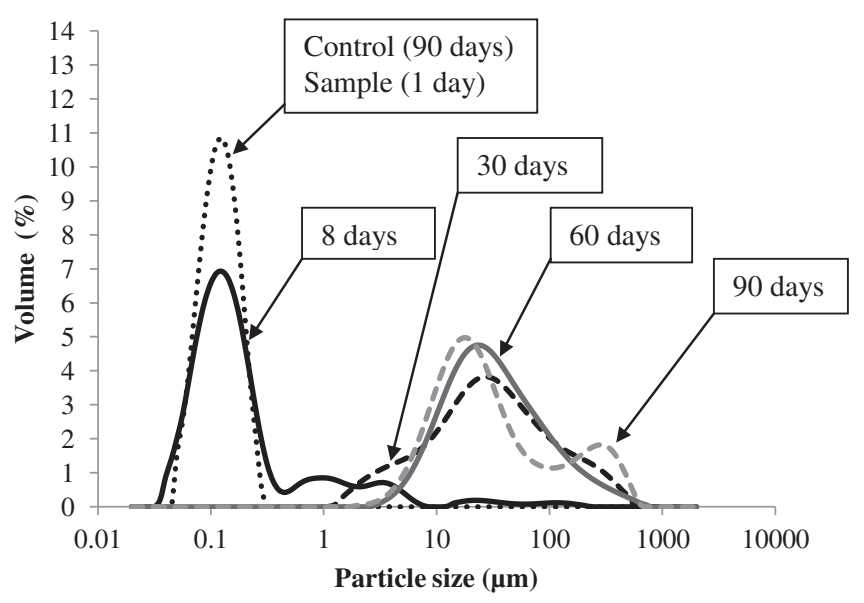

Fig. 7. Particle size distribution of control UHT milk (after 90 days of storage) and UHT milks containing AprX during 90 days of storage at $20^{\circ} \mathrm{C}$.

\section{Discussion}

The phenomenon of destabilisation of milk with formation of gel or sediment exists. This problem is a sign of a bad quality for the industrial and the customer. Thus, identifying the causes of this instability is a scientific challenge. It is known, that the presence of Ps. fluorescens in raw milk can be a possible cause. Indeed, this species produces a heat-resistant and extracellular protease, AprX, that could modify the physico-chemical properties of casein micelles and lead to the destabilisation of UHT milk during its storage. To confirm this hypothesis and to understand the physico-chemical modifications of casein micelles by AprX enzyme, the consequence of the addition of the purified enzyme to raw milk before UHT treatment has been investigated.

The addition of AprX at a concentration of $0.2 \mathrm{mg} \mathrm{L}^{-1}$ induced proteolysis of casein micelles, leading to the destabilisation of the UHT milk during storage. At this concentration, the destabilisation was visual, with the presence of sediment after only 8 days of storage (Fig. 1).

The increase IN NCN and NPN content (Fig. 3) during the first week of storage was due to the proteolysis of caseins. The analysis of the NCN fractions by RP-HPLC confirmed the presence of peptide materials in these fractions (Fig. 4). Some studies reported also high levels of proteolysis (Celestino, Iyer, \& Roginski, 1997; Gaucher et al., 2009, 2011; Rattray, Gallmann, \& Jelen, 1997). The number of different peptides detected by mass spectrometry was more important for $\beta->\alpha_{S^{-}}>\kappa^{-}=\alpha_{S 2}$-caseins (Fig. 5, Table 1). A similar order was observed in different studies of milk contaminated with Ps. fluorescens CNRZ 798 and Ps. fluorescens F (Gaucher et al., 2009, 2011) as well as unstable commercial milk samples (Baglinière et al., 2012).

For $\kappa$-casein (Fig. 5D), the main peptides detected came from the sequence $105-125$, but the number of peptides was low. This could be due to the low quantity of $\kappa$-casein in the milk (about $3.5 \mathrm{~g} \mathrm{~L}^{-1}$ ) and the difficulty of identifying glycosylated peptides (N-terminal part) by mass spectrometry with an automated peptide identification workflow such as the one used in this study. Moreover, covalent interactions between $\beta$-lactoglobulin and $\kappa$-casein are possible after UHT treatment (Singh \& Creamer, 1992) and could decrease the accessibility of $\kappa$-casein to the enzyme AprX. No specific cleavage site by AprX was identified for the four caseins suggesting that AprX had a large activity spectrum.

In spite of low quantity of peptides coming from $\kappa$-casein, the stability of casein micelles can apparently be affected by this hydrolysis, leading to the destabilisation of the UHT milk. This 
Table 2

General characteristics of UHT milks containing AprX (after 8 days of storage) or contaminated by Pseudomonas fluorescens $\mathrm{F}^{\mathrm{a}}$

\begin{tabular}{|c|c|c|c|}
\hline Characteristic & $\begin{array}{l}\text { Control } \\
90 \text { days }\end{array}$ & $\begin{array}{l}\text { AprX } \\
8 \text { days }\end{array}$ & $\begin{array}{l}\text { Ps. fluorescens } \mathrm{F} \\
90 \text { days }\end{array}$ \\
\hline Visual destabilisation & No & Yes & Yes \\
\hline Zeta potential (mV) & -17.2 & -13.9 & -13.4 \\
\hline $\begin{array}{l}\text { Micellar hydration } \\
\quad\left(\mathrm{g}^{-} \text {water } \mathrm{g} \text { dried } \text { pellet }^{-1} \text { ) }\right.\end{array}$ & 2.1 & 1.3 & 1.4 \\
\hline $\mathrm{NCN}\left(\mathrm{g} \mathrm{kg}^{-1}\right)$ & 3.1 & 9.2 & 7.3 \\
\hline $\mathrm{NPN}\left(\mathrm{g} \mathrm{kg}^{-1}\right)$ & 1.4 & 6.4 & 4.0 \\
\hline
\end{tabular}

a Data for characteristics of UHT milk contaminated by Pseudomonas fluorescens $\mathrm{F}$ are after 90 days of storage and are taken from Baglinière et al. (2012). Control UHT milk corresponds to milk without contamination by Ps. fluorescens or AprX.

destabilisation of casein micelle was seen as a decrease in hydration and zeta potential (Fig. 6A and B). These decreases reduced the repulsions between casein micelles, leading to the formation of aggregates and the destabilisation of UHT milk (Fig. 7).

In a previous study (Baglinière et al., 2012), similar experiments were conducted with the Ps. fluorescens strain F and similar results were found, but the kinetics of destabilisation was different. After 90 days of storage, the UHT milk containing AprX was destabilised, with the presence of aggregates (Fig. 7). Increases in NCN and NPN (Fig. 3) and also decreases in hydration (Fig. 6A) and zeta potential (Fig. 6B) of casein micelles were observed during the storage of enzyme-treated UHT milk. The destabilisation was slower than that observed in this study with purified AprX. The characteristics of UHT milk samples containing AprX and stored 8 days (values of NCN and NPN contents, hydration, zeta potential, number and types of peptides in NCN faction) are closed to those of UHT milk contaminated by the strain $\mathrm{F}$ after 90 days of storage (Table 2, Baglinière et al., 2012). The differences observed could be due to a higher quantity of AprX in the milk in this study than in the experiment studying the strain Ps. fluorescens F (Baglinière et al., 2012).

Thus, the similar results obtained in the study carried out by Baglinière et al. (2012) with the strain F and in the present work were consistent with the proposition that the proteolysis by Ps. fluorescens leading to the destabilisation of milk was primarily due to the activity of AprX. Moreover, the destabilisation of the contaminated milk after UHT treatment confirmed that this enzyme was heat-resistant.

\section{Acknowledgements}

Authors would like to thank CNIEL (National Interprofessional Center of the Dairy Economy) for the financial support.

\section{References}

Adams, D. M., Barach, J. T., \& Speck, M. L. (1975). Heat resistant proteases produced in milk by psychrotrophic bacteria of dairy origin. Journal of Dairy Science, 58, $828-834$.

Adams, D. M., Barach, J. T., \& Speck, M. L. (1976). Effect of psychrotrophic bacteria from raw milk on milk proteins and stability of milk proteins to ultrahigh temperature treatment. Journal of Dairy Science, 59, 823-827.

Ahn, J. H., Pan, J. G., \& Rhee, J. S. (1999). Identification of the tliDEF ABC transporter specific for lipase in Pseudomonas fluorescens SIK W1. Journal of Bacteriology, 181, 1847-1852.

Baglinière, F., Tanguy, G., Jardin, J., Matéos, A., Briard, V., Rousseau, F., et al. (2012). Quantitative and qualitative variability of the caseinolytic potential of different strains of Pseudomonas fluorescens: implications in the stability of casein micelles of UHT milk samples during their storage. Food Chemistry, 13, 2593-2603.
Bouzerzour, K., Morgan, F., Cuinet, I., Bonhomme, C., Jardin, J., Le Huërou-Luron, I., et al. (2012). In vivo digestion of infant formula in piglets: protein digestion kinetics and release of bioactive peptides. British Journal of Nutrition, 108, 21052114.

Celestino, E. L., Iyer, M., \& Roginski, H. (1997). Reconstituted UHT-treated milk: effects of raw milk, powder quality and storage conditions of UHT milk on its physico-chemical attributes and flavour. International Dairy Journal, 7, $129-140$.

Dherbecourt, J., Falentin, H., Jardin, J., Maillard, M. B., Baglinière, F., Barloy-Hubler, F., et al. (2010). Identification of a secreted lipolytic esterase in Propionibacterium freudenreichii, a ripening process bacterium involved in Emmental cheese lipolysis. Applied and Environmental Microbiology, 76, 1181-1188.

Dogan, B., \& Boor, K. J. (2003). Genetic diversity and spoilage potentials among Pseudomonas spp. isolated from fluid milk products and dairy processing plants. Applied and Environmental Microbiology, 69, 130-138.

Dufour, D., Nicodème, M., Perrin, C., Driou, A., Brusseaux, E., Humbert, G., et al. (2008). Molecular typing of industrial strains of Pseudomonas spp. isolated from milk and genetical and biochemical characterization of an extracellular protease produced by one of them. International Journal of Food Microbiology, 125, 188-196.

Gaucher, I., Mollé, D., Gagnaire, V., Léonil, J., Rousseau, F., \& Gaucheron, F. (2009). Destabilisation of commercial UHT milk samples: proteolysis and changes in milk particles. Milchwissenchaft, 64, 43-47.

Gaucher, I., Tanguy, G., Fauquant, J., Jardin, J., Rousseau, F., Robert, B., et al. (2011). Proteolysis of casein micelles by Pseudomonas fluorescens CNRZ 798 contributes to the destabilisation of UHT milk during its storage. Dairy Science and Technology, 91, 413-429.

Griffin, M. C. A., \& Griffin, W. C. (1985). A simple turbidimetric method for the determination of the refractive index of large colloidal particles applied to casein micelles. Journal of Colloid and Interface Science, 104, 409-415.

IDF. (2001). Determination of nitrogen content. Part 4: Determination of non-proteinnitrogen content, Standard FIL-IDF 20-4. Brussels, Belgium: International Dairy Federation.

Liao, C. H., \& McCallus, D. E. (1998). Biochemical and genetic characterization of an extracellular protease from Pseudomonas fluorescens CY091. Applied and Environmental Microbiology, 64, 914-921.

McPhee, J. D., \& Griffiths, M. W. (2011). Psychrotrophic bacteria, Pseudomonas spp. In J. W. Fuquay, P. F. Fox, \& P. L. H. McSweeney (Eds.), Encyclopedia of dairy sciences (2nd ed.). (pp. 379-383) London, UK: Academic Press.

Marchand, S., Vandriesche, G., Coorevits, A., Coudijzer, K., De Jonghe, V., Dewettinck, K, et al. (2009). Heterogeneity of heat-resistant proteases from milk Pseudomonas species. International Journal of Food Microbiology, 133, 68-77.

Martins, M. L., de Araujo, E. F., Mantovani, H. C., Moraes, C. A., \& Vanetti, M. C. (2005). Detection of the apr gene in proteolytic psychrotrophic bacteria isolated from refrigerated raw milk. International Journal of Food Microbiology, 102, 203211.

Martins, M. L., Pinto, C. L. O., Rocha, R. B., de Araujo, E. F., \& Vanetti, M. C. D. (2006). Genetic diversity of Gram-negative, proteolytic, psychrotrophic bacteria isolated from refrigerated raw milk. International Journal of Food Microbiology, 111, 144-148.

Nicodème, M., Grill, J. P., Humbert, G., \& Gaillard, J. L. (2005). Extracellular protease activity of different Pseudomonas strains: dependence of proteolytic activity on culture conditions. Journal of Applied Microbiology, 99, 641-648.

Nörnberg, M. F. B. L., Friedrich, R. S. C., Weiss, R. D. N., Tondo, E. C., \& Brandelli, A. (2010). Proteolytic activity among psychrotrophic bacteria isolated from refrigerated raw milk. International Journal of Dairy Technology, 63, 41-46.

Rattray, W., Gallmann, P., \& Jelen, P. (1997). Nutritional, sensory and physicochemical characterization of protein-standardized UHT milk. Lait, 77, 279-296.

Richardson, B. C., \& Te Whaiti, I. E. (1978). Partial characterization of heat-stable extracellular proteases of some psychrotrophic bacteria from raw milk. New Zealand Journal of Dairy Science and Technology, 13, 172-176.

Singh, H., \& Creamer, L. K. (1992). Heat stability of milk. InP. F. Fox (Ed.). Advanced dairy chemistry: Proteins, Vol. 1, (pp. 621-656). Cambridge, UK: Elsevier Science Publishers Ltd.

Smoluchowski, M. (1917). Versuch einer mathematischen Theorie der Koagulationskinetik kolloider Lösungen. Zeitschrift fur Physikalische Chemie-International, 92, 129-168.

Sørhaug, T., \& Stepaniak, L. (1997). Psychrotrophs and their enzymes in milk and dairy products: quality aspects. Trends in Food Science and Technology, 8, 35-40.

Teh, K. H., Flint, S., Palmer, J., Lindsay, D., Andrewes, P., \& Bremer, P. (2011). Thermoresistant enzyme-producing bacteria isolated from the internal surfaces of raw milk tankers. International Dairy Journal, 21, 742-747.

Wang, L., \& Jayaro, B. M. (2001). Phenotypic and genotypic characterization of Pseudomonas fluorescens isolated from bulk tank milk. Journal of Dairy Science, 84, 1421-1429.

Woods, R. G., Burger, M., Beven, C. A., \& Beacham, I. R. (2001). The aprX-lipA operon of Pseudomonas fluorescens B52: a molecular analysis of metalloprotease and lipase production. Microbiology, 147, 345-352. 